\title{
MEASURABLE PERFORMANCE INDICATORS OF BUSINESS PROCESSES AND PERFORMANCE OF SLOVAK AND FOREIGN BUSINESSES
}

\author{
Katarína Gašová, ${ }^{1}$ Martina Kováčiková, ${ }^{2}$ Katarína Repková Štofková3
}

\begin{abstract}
Business activities (managerial, administrative, commercial, manufacturing, etc.), which are focused on production or the services provision should be managed as a whole, containing the activities liable to certain logistic in their arrangement and interconnection. The business activities' transformation on processes and management (identification, modelling, mapping, analysis, measurement and improvement) through the process management can be understood as a type of methodology suitable for the analysis, evaluation and improvement of key processes in the business.

An aim of the application of business process management is to create a process model consisting of managerial, core, transparency supporting, measurable, and possible improvement processes. The principles of business process management application can lead to continuous improvement of business processes and to the position improvement of the business in a constantly evolving competitive environment. During the evaluation process, it is important to focus on one of the most important factors - the measurability of process performance.
\end{abstract}

JEL Classification Numbers: D00, D24, J24; DOI: http://dx.doi.org/10.12955/cbup.v5.915

UDC Classification: 658.6

Keywords: process, key performance indicators, critical success factors

\section{Introduction}

In the competitive business environment, the number of businesses applying principles of the business process management is currently increasing with an emphasis on the efficient management of processes to ensure the achievement of aims at the required quality and at a specified standard. An appropriate implementation of business process management also brings high productivity and profit. An effective process management requires the measurement of their performance. In the context of the business processes performance measurement - the efficiency of business processes - we mean the Key Performance Indicators (KPIs). KPIs quantify the performance of the monitored process in regard to the process output (added value of process).

\section{Business processes}

The process is characterized by the input, transformation, and output. At a closer look, it is possible to specify responsibility, owner, customer, sponsor, time parameters, boundaries, repeatability and the resources of process. Business processes can be classified by various criteria. The most common classification is to: management, core (main business, key) and support (service and section) processes. Internal and external processes can be specified in regard to the internal and external business environment i.e. to the orientation of process output on the internal or external customer (Soltes \& Repkova Stofkova, 2016).

The authors Dzubakova \& Lichnerova (2012), Hromkova \& Holociova (2005) cite Earl's classification of business processes:

- Core processes - relate directly to the external customer and are critical to functioning of the business.

- Support processes - are tasked to support core processes and create suitable conditions.

- Business network processes - transcend business boundaries and directly impact the competitiveness of the business. These processes focus on business partners, customers and suppliers.

- Management processes - impact the internal efficiency of the business. Represent the planning, organizing and managing resources.

Tucek \& Zamecnik (2007) cite the classification by Edwards and Peppard, who differentiate four types of business processes according to product and components of market oriented business strategy:

\footnotetext{
${ }^{1}$ Faculty of Operation and Economics, University of Žilina, Slovak Republic, katarina.gasova@ fpedas.uniza.sk

${ }^{2}$ Faculty of Operation and Economics of Transport and Communications, University of Žilina, Univerzitná 1, 010 26, Žilina,

Slovak Republic, martina.kovacikova@fpedas.uniza.sk

${ }^{3}$ Faculty of Operation and Economics, University of Žilina, Slovak Republic, katarina.stofkova@ fpedas.uniza.sk
} 
- Competitive processes - are focused on the competitors with the aim to improve the competitive position of the business. From an economic perspective, these processes ensure profit for the business.

- Infrastructure processes - focus on human resources, processes and technology, i.e. they are crucial for the efficient future of the business.

- Core processes - represents essential business processes important for remaining competitive. They are valued by process customers, i.e. customers, suppliers, employees and other stakeholders.

- Support processes - are necessary to be carried out in a business however, are not appreciated by stakeholders.

Dzubakova \& Lichnerova (2012) give a different view of the processes classification, which was brought by Kaplan and Norton (Kaplan \& Norton, 1993). They categorize business processes to:

- Innovation processes - the main parts are research and development, which affect the competitive position of the business.

- Operations processes - run inside the business and are focused on production. These processes begin with the order and end with product delivery.

- Post-sales processes - services, following the sale, e.g. customer service.

In all mentioned classifications can be identified as major processes, which are crucial for the functioning of the process and also the processes, are used for the proper business functioning, and which support the performance of core processes.

\section{Business processes evaluation and measurement}

Each business performs process optimisation with regard to the Critical Success Factor (CSF) of business. Critical factors represent areas that businesses want to improve and by that increase their competitive advantage. Some authors claim that CSF are conditions which businesses must meet to be able to achieve their outlined strategic aims. CSF can be considered as business milestones. In compliance with the concept of CSF they represent the definition of the most important factors for business success. CSF are also referred to as key success factors so that these terms can be therefore be regarded as synonymous. The most common CSF which businesses seek to achieve are improvement on: customer satisfaction, quality, product delivery, employee satisfaction, productivity, financial performance, safety, environmental performance, social behaviour, price, the best suppliers, the best sellers etc. indicated by Zavadsky (2004) and Stofko et al (2016).

Changes in business process are carried out according to key success factors. However, it is necessary to obtain accurate and objective information about the progress of processes and sub-processes to be able to evaluate the made changes. This information is obtained by the process performance measurement. A term of the process measurement includes activities, which provide accurate and objective information about the process flow. This information is used mainly by process owners in operation management. According to this available information, process owners are able to meet all the requirements of the process (Triad, 2015).

It is necessary to secure the completeness, sufficient level of detail, and validity of the measurement to obtain the relevant results of the process performance measurement (input, flow, output). In the context of the measurement it is necessary to set the frequency and accuracy of the measurement and also to identify deviations from the different requirements in different locations of the process or to accept the seasonality of specific phenomena. The realisation of processes' performance measurement requires the definition of the indicator, based on which it will be possible to quantify the business performance. The most commonly used quantification units are units of: time, percentages, currency or quantity (piece, volume, weight and length measures). The measurement results should be presented in an intelligible, clear and univocal manner, i.e. the key performance indicator have to be defined unambiguously.

The relationship between Critical Success Factors (CSF) and key performance indicators (KPI) is also defined in a set of ITIL book publications (ITIL, 2015) (Figure 1). 


\begin{tabular}{|c|c|}
\hline Figure 1: Continual service improvement - Relationship between CSF a KPI \\
\hline vision $>$ mission $>$ goals $>$ focus $>$ CFS $>$ KPI $>$ metrics $>$ measurements \\
\hline Source: Authors
\end{tabular}

According to ITIL (set of book publications, containing a collection of the best practices from the discipline of management and information technology services and is owned by the British company AXELOS, Ltd.), each business should define appropriate CSF derived from the process purpose. A further level represents the determination of key performance indicator derived from the defined CSF. The determination and acceptance of KPI should be carefully considered, whether the KPI actually results from the CSF and corresponds to the level of business. Businesses should constantly monitor the determined KPI because it can signal a deterioration of process performance as well as identify opportunities for process improvement (OMNICOM, 2016).

\section{Key performance indicators}

KPI are defined as indicators or performance metrics associated with the process, the product, the service, and the whole business or part of it. KPI are tasked to quantify the performance of business as a whole, in regard to a determined top aim of the business i.e. the critical success factor. However, the business performance is a result of the performance of the individual parts and business processes. Therefore, it is necessary to correctly select the appropriate KPI, but also to choose a suitable activity to be linked with the KPI as equally indicated by Dzubakova \& Lichnerova (2012) and others (Management Mania, 2016). KPI should be quantifiable and should enable business to determinate measurable aims, monitor, identify and predict trends. In some cases, KPI should provide preventive, remedial, and improving measures. Top management of the business should establish KPI as a basis for strategic and tactical decisions. KPIs should be suitably selected and assigned to the relevant functions and levels of the business, depending on the processes structure and should thus support the monitoring of the achievement level of top aims (Martisovic, 2016).

A substantial part of process performance measurement is the process of determining the specific process performance indicator. The key is to correctly identify and define the process. Thereafter the predetermined team provide a substantial analysis of possible indicators, which result in the specification of the most appropriate indicators of inputs for the process performance measurement (Klbko, 2016).

\section{Types of measurable indicators}

Measurable performance indicators can be divided into several categories according to business focus and the nature of business products. In this regard, it is possible to specify universal performance indicators, production processes performances indicators, and performance indicators of nonproduction processes (Repa, 2006).

Universal performance indicators represent indicators which can be used to measure various processes and are not tied to a particular or specific process. There exist many universal indicators, but the most used are:

- Effective use of process time - it is a ratio of processing time to process continuous period.

- Ongoing process time - represents the time which elapses from the time of acceptance of the process input to final output of the process.

- Total process costs - are composed of the conformity and non-conformity costs.

- Effective use of costs - is a ratio of the conformity costs to the overall costs of the process.

- Mismatches ratio of process - is the ratio of the mismatches identified during the process to volume of matched output of the process.

- Number of registered deviations in the process (Loucanova et al., 2015).

Production processes performances indicators are mainly used for operational management of production. The most common and the well known performance indicators include: the value of production-in-progress, the percentage of downtime on the available machine capacity, worker productivity, machine productivity, capital productivity, overall efficiency of the device, the 
proportion of defective products to total output, number of worked hours, elasticity in response to a change in production, the number of suggestions for improvement and many others (Klbko, 2016).

Non-production process represents each process, except production, which flow in businesses during the course of product realization. Non-production processes can take place before the start of production (development, marketing, etc.), during the course of production (repairs, maintenance, etc.) or after production (import, service, etc.). The best known and most widely used performance indicators of non-production processes are: the evaluation of suppliers, the reaction rate to mismatches notified by customers, the share of scheduled orders to realised contracts, the cost to retrieve suitable suppliers, the time of placing a new product on the market, the return on investment for design and development, the share of maintenance costs of the total costs, the share of new requirements for service to all the unmet needs etc. mentioned by Free ITIL training (ITIL, 2011).

In regard to other measurement elements is the process-oriented standard: STN EN ISO 9001 which complements the aforementioned key performance indicators of production, non-production and universal processes of performance measurement by variations (delays of supplied material and information input, defects of tools and equipment, unprepared or incompetent staff etc.) and by the index performance measurement (data recorded for evaluation: time of measurement, names of used indicators, weight of indicators etc.) referred to in ISO 9001 (ISO, 2011).

Another categorization of process performance measurement indicators can be focused on specific attributes or the characteristics of processes. In this regard, it is possible to specify the orientation to animate and inanimate attributes of a particular process.

\section{Data and methodology}

Authors used professional literature published in the field of process management during the literature review. Information from the statistical offices' web pages were used during the research. This information represents secondary data sources. Authors focused mainly on the analysis of options for process improvement in context of process management i.e., the analysis of the process evaluation and performance measurement. The most attention was devoted to the comparison of the European Union countries based on the labor productivity per hour. The labor productivity per hour is an indicator considered as a coefficient of performance relating to operative processes in general, in regard to the comparison of countries.

Various methods were used during the research. Methods of professional literature selection, induction and deduction were used during the literature review. Authors carried out the analysis and synthesis necessary for the determination of mutual influence between the established facts. A method of comparison was used to compare the findings of the European Union member countries to the established performance indicator. The methods of induction and deduction were used during the whole contribution. Authors used MS Excel and PowerPoint as a basis for the graphic and image processing.

\section{Comparison of the Slovak and foreign businesses performance}

Labour productivity can be used for the comparison of the performance of businesses in different countries as described below. The contribution of Horvathova \& Suhanyiova (2012) claims that there is a significant difference between the performance of Slovak and foreign businesses. However, this difference does not consist of differences in employees' education or technology disparities of business equipment, because Slovak businesses are at the same or very similar level in these areas as businesses abroad. The difference consists mainly of the processes arrangement and their effective management and flow. This situation is a result of the fact that foreign businesses are currently dealing with issues of process management more than Slovak businesses. Foreign companies pay more attention to processes and the elimination of barriers for the most efficient process flow within the business. It is necessary to verify and prove that businesses abroad, particularly in developed countries, actually perform better than businesses in Slovakia. On the assumption that inputs, education and technological equipment are comparable in different countries and that conditions for businesses are approximately at the same level, then it is possible to compare the performance of businesses in different countries with the use of labor productivity per employee or labor productivity per hour worked. Labour productivity per hour worked provides objective information about 
productivity because the assessment of labor productivity per employee does not take into account the types of employment contract and real worked time.

According to EUROSTAT (2016), the labor productivity per hour worked in Slovakia was $13.2 €$ in 2013. In France, Belgium, Sweden, Ireland and the Netherlands had a level of labor productivity per hour worked at the level from $45 €$ to $48 €$. The highest labor productivity per hour worked reached Denmark. Lower productivity compared to Slovakia reached Bulgaria, the Czech Republic, Estonia, Latvia, Lithuania, Hungary, Poland, and Romania. The lowest labor productivity among the surveyed countries in 2013 was recorded in Bulgaria at the level of $4.9 €$. We processed the statistical pages of PORDATA (2017) to give a different perspective on monitored issue. The following figure expresses a graphically processed comparison of the monitored indicator in 1995 and 2015 ("-_ represents unavailable information) (Figure 2).

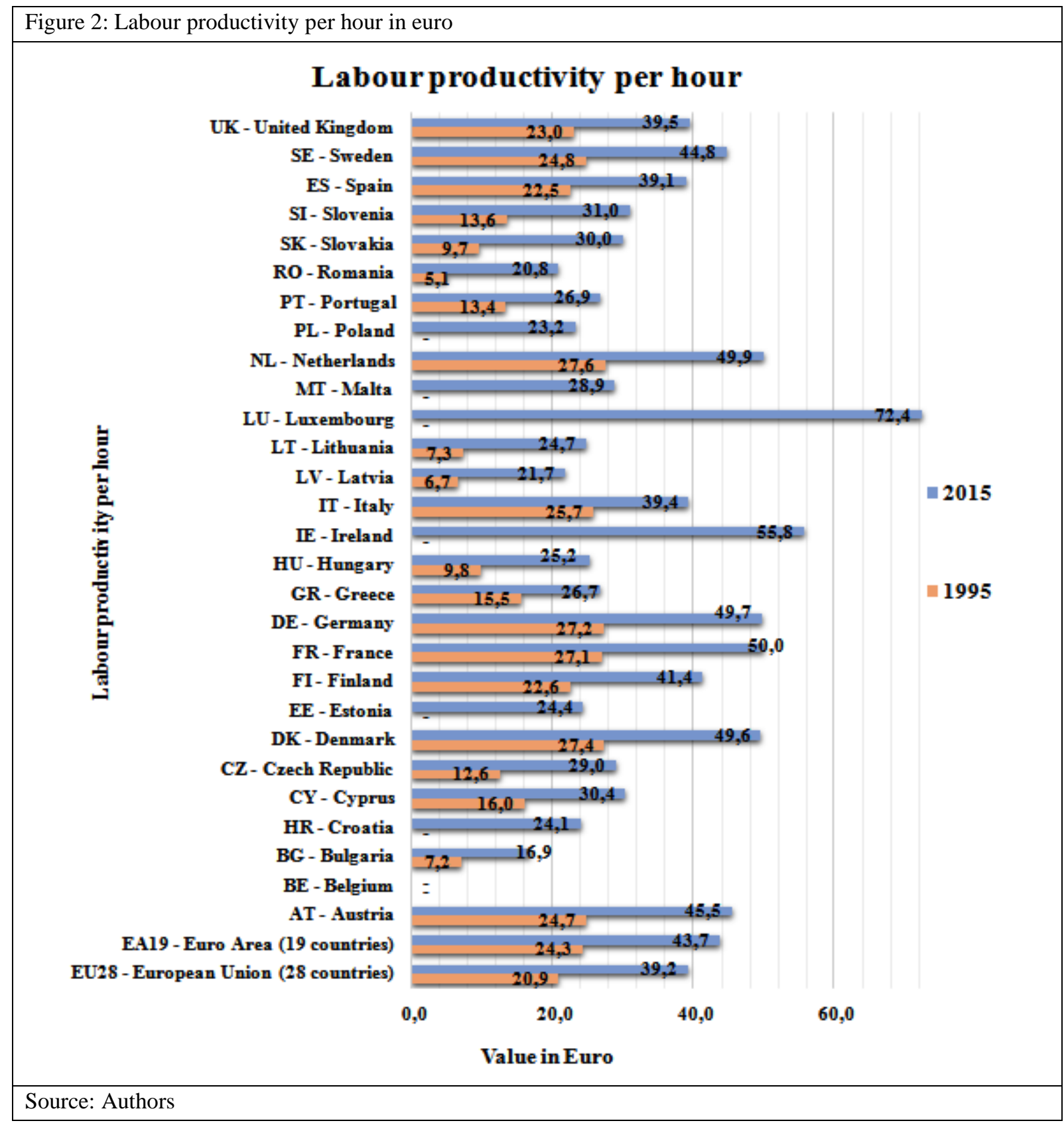

In the context of the trend formation, the statistical pages suggest that according to the measurable performance indicator - labor productivity per hour worked - that Ireland will be the leader in the future. 


\section{Conclusions}

Processes are very important part of every business. The setting and types of processes in the business affects its functioning, but particularly its performance. However, not all businesses realize the importance of processes. They do not have processes explored and mapped and thus do not see opportunities for improvement. Business process improvement is currently considered as a prerequisite for a successful business. It should run continuously, with the acceptance of measurable indicators, setting KPI and CSF, to bring a change, which will have a positive impact on the business.

Prosperity, productivity, business flexibility is reflected in the prosperity of the country and also in the citizens' standard of living. We used labor productivity per hour worked expressed in Euros as an indicator of the countries performance in the contribution. The growing trend of monitored labor productivity per hour worked was generally observed. Nevertheless, the Nordic countries still occupy leading positions in regard to the measure of labor productivity per hour, while Luxembourg dominates from all of the Western Europe countries. From the V4 member countries we see Slovakia and the Czech Republic to be almost equal.

Based on the findings we can partially confirm the above statement, that foreign businesses operating in the developed countries perform better than businesses operating in Slovakia. Therefore, it is possible to assume that the management oriented on business processes have a key importance.

\section{Acknowledgements}

This contribution was undertaken as a part of research project VEGA 1/0733/15 and VEGA 1/0693/16.

\section{References}

Dzubakova, M., \& Lichnerova, L. (2012). Procesny manazment. Bratislava, Slovak Republic: EKONOM. 134 p.

EUROSTAT (2016) Retrieved April, $1^{\text {st }} 2016$ from http://ec.europa.eu/eurostat/

tgm/table.do?tab=table\&init=1\&plugin=1\&language $=$ en\&pcode $=$ tsdec 310

Horvathova, J. \& Suhanyiova, A. (2012). Balanced Scorecard - nastroj riadenia podnikov a ich udrzatelnosti v case krizy. Retrieved February, 26 ${ }^{\text {th }} 2016$ from http://www.cutn.sk/Library/proceedings/mch_2012/editovane_prispevky/Horv\%C3 \%A1thov\%C3\%A1_Suh\%C3\%A1nyiov\%C3\%A1.pdf

Hromkova, L., \& Holociova, Z. (2005). Teorie prumyslovych podnikatelskych systemu. Zlin, Czech Republic: UTB ve Zline. $112 \mathrm{p}$.

ISO (2011). ISO 9001 System manazmentu kvality. Retrieved April, $28^{\text {th }} 2016$ from https://managementmania.com/sk/iso9001

ITIL (2011). Free ITIL training. Retrieved February, $19^{\text {th }} 2016$ from http://www.slideshare.net/RDSWEB/free-itil-training

ITIL (2015). Continual service improvement. Retrieved February, $02^{\text {nd }} 2015$ from http://www.hci-

itil.com/ITIL_v3/books/5_service_improvement/service_i mprovement_ch4_1 .html

Kaplan, R. S. \& Norton, D. P. (1993). Putting the Balanced Scorecard to Work, Harvard Business Review, No 5, pp 134-147.

Klbko (2016). Levik o nas. Retrieved April, $28^{\text {th }} 2016$ from http://levik.sk/sk/content/4-o-nas

Loucanova, E. et al. (2015). Innovation activities in micro and small companies in Slovakia. Proceedings International Scientific Conference on Globalization and its Socio-Economic consequences. Vol. 15. pp 378-381.

Management Mania (2016). KPI (Key Performance Indicators) - klucove ukazovatele vykonnosti. Retrieved February $04^{\text {th }}$ 2016 from https://managementmania.com/sk/kpi-keyperformance-indicators-klucove-ukazovatele-vykonnosti

Martisovic, R. (2016). KPI. Retrieved February, 04 ${ }^{\text {th }} 2016$ from http://www.produktivne.sk/metody-stihlej-vyroby2/kpi/ OMNICOM (2016). Co je to ITIL®. Retrieved January, $20^{\text {th }} 2016$ from http://www.bestpractice.sk/sk/Best-practice/-ITSMITIL/Co-je-to-ITIL-.alej

PORDATA (2017). Labour productivity per hour. Retrieved March, $10^{\text {th }} 2017$ from http://www.pordata.pt/en/DB/Europe/Search+Environment/Table

Repa, V. (2006). Podnikove procesy: procesni rizeni a modelovani. Praha, Czech Republic: Grada Publishing. 265 p.

Soltes, V. \& Repkova Stofkova, K. (2016). Business environment as an indicator of regional disparities. CBU International Conference Proceedings, http://dx.doi.org/10.12955/cbup.v4.760.

Stofko, S., Soltes, V., Stofkova, Z. (2016). Options of using the integrated management system. In: Proceedings International Conference on Engineering Science and Production Management (ESPM). pp 267-272.

Triad. (2015, March 23th). Co je KPI? Retrieved February, 04 ${ }^{\text {th }} 2016$ from http://blog.triad.sk/marketingovy-slovnik/co-sukpis/

Tucek, D., \& Zamecnik, R. (2007). Rizeni a hodnoceni vykonnosti podnikovych procesu v praxi. Zvolen, Slovak Republic: Technicka univerzita vo Zvolene. $206 \mathrm{p}$.

Zavadsky, J. (2004). Procesny manazment. Banska Bystrica, Slovak Republic: Univerzita Mateja Bela. 147 p. 